This item was submitted to Loughborough's Research Repository by the author.

Items in Figshare are protected by copyright, with all rights reserved, unless otherwise indicated.

\title{
Wettest December in the Lake District for over 200 years
}

\section{PLEASE CITE THE PUBLISHED VERSION}

http://dx.doi.org/10.1002/wea.2711

\section{PUBLISHER}

Wiley / @ Royal Meteorological Society

\section{VERSION}

AM (Accepted Manuscript)

\section{PUBLISHER STATEMENT}

This work is made available according to the conditions of the Creative Commons Attribution-NonCommercialNoDerivatives 4.0 International (CC BY-NC-ND 4.0) licence. Full details of this licence are available at: https://creativecommons.org/licenses/by-nc-nd/4.0/

\section{LICENCE}

CC BY-NC-ND 4.0

\section{REPOSITORY RECORD}

Wilby, Robert, and Philip A. Barker. 2019. "Wettest December in the Lake District for over 200 Years". figshare. https://hdl.handle.net/2134/21307. 


\section{Wettest December in the Lake District for over 200 years}

The year 1788 was notable for many reasons. The first permanent European settlement (Sydney) was established in Australia; Mozart completed his Symphony No.39; New York ratified the United States Constitution; Prime Minister Robert Peel was born; and Charles Wesley founder of Methodism died. The following year saw the start of the French Revolution. More than two centuries have passed after these prominent historical events but, since then, the English Lake District in Cumbria has not experienced a wetter December than in 2015 (Table 1).

Table 1 Largest December precipitation totals $(\mathrm{mm})$ in the Central English Lake District with year of occurrence and percentage of 1981-2010 mean

\begin{tabular}{|l|l|l|}
\hline Rank & Total (year) & \% average \\
\hline 1 & $720(2015)$ & 269 \\
\hline 2 & $658(1852)$ & 246 \\
\hline 3 & $626(1833)$ & 234 \\
\hline 4 & $582(1824)$ & 217 \\
\hline 5 & $494(2014)$ & 184 \\
\hline
\end{tabular}

Our updated Central English Lake District (CELD) index is constructed by overlapping monthly precipitation records from Kendal (1788-1899), Keswick (17901879), Grasmere (1870-1950), and Rydal (1901-present) (Barker et al., 2004). Seasonal correction factors are used to bridge all the records to Grasmere, thereby creating a continuous series since 1788 (with just a few missing years in 1796-1801 and 1803-1805) (Figure 1). The CELD index is highly correlated with the Met Office regional precipitation series for Northwest England, a very long record for Carlisle, as well as with river flows into Stocks and Thirlmere reservoirs.

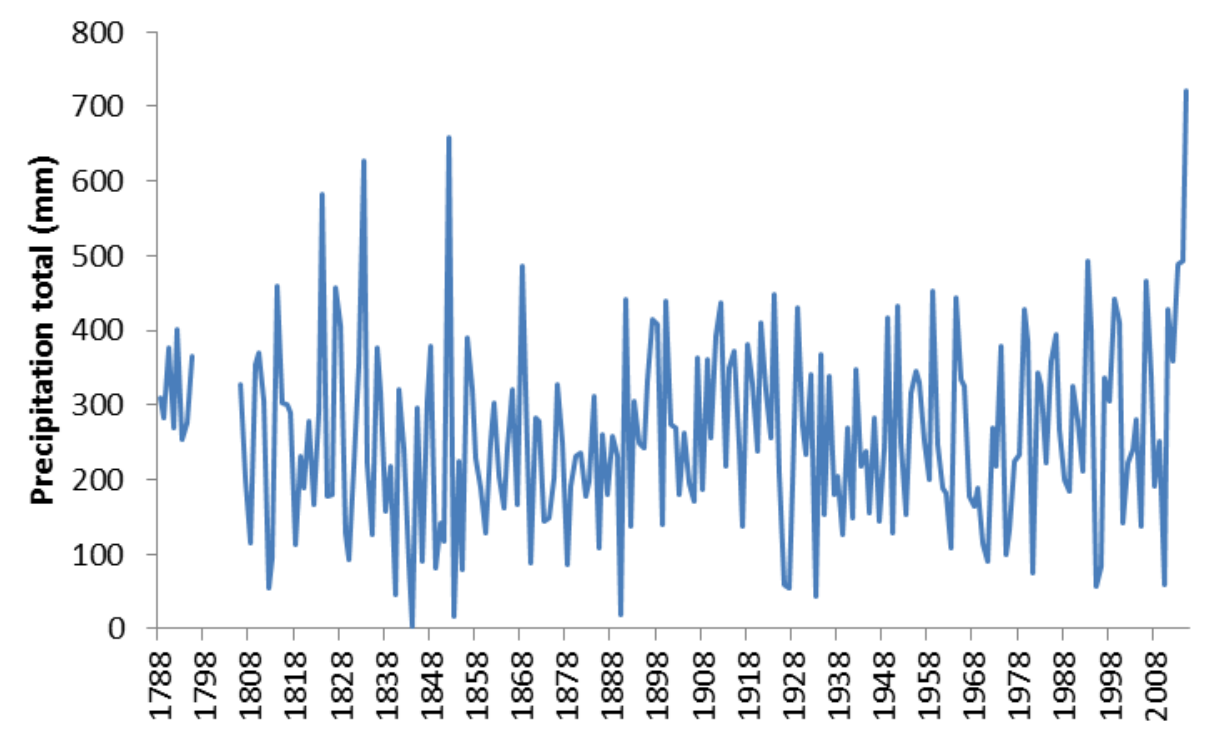

Figure 1 December precipitation for the Central English Lake District 1788-2015 
November and December 2015 were remarkable because of the relentless passage of rain-bearing fronts and low pressure systems such as Storms Desmond, Eva and Frank. During these two months, there were at least 16 days on which the rainfall total exceeded $25 \mathrm{~mm}$. In cooler years, much of this precipitation might have remained on the fells as snowpack. But December 2015 was also the warmest on record by a wide margin.

Aside from the record-breaking December, other recent years have been conspicuously wet. December 2015 followed the fourth wettest November in our series and, together, they contributed to the fifth largest annual total since 1788 . So far, the 21st century has witnessed five top 10 wettest years in the CELD series (2000 [3rd], 2008 [9th], 2009 [6th], 2011 [8th], 2015 [5th]) as well as the second wettest winter (2013/14) and second wettest summer (2012).

December 2015 was not quite the wettest of all months in the CELD series - this dubious honour falls to November $2009(731 \mathrm{~mm})$. However, provisional data supplied by the Met Office suggest that the December 2015 total may be underestimated because of rain gauge overflows. We plan to perform further checks using other sources of quality assured data as these become available.

The astonishing rainfall statistics for December 2015 will provide no comfort to those who have flood damaged homes and businesses. However, from the perspective of more than two centuries, these were truly exceptional events. The underlying causes of the recent clustering of wet seasons warrant further investigation.

Professor Robert L. Wilby, Department of Geography, Loughborough University, Loughborough, LE11 3TU, UK r.l.wilby@lboro.ac.uk

Professor Philip A. Barker, Lancaster Environment Centre, Lancaster University, Lancaster, LA1 4YQ, UK p.barker@lancaster.ac.uk

Source: Barker, P.A., Wilby, R.L. and Borrows, J. 2004. A 200-year precipitation index for the central English Lake District. Hydrological Sciences Journal, 49, 769785. 